\title{
The chronology of adipose tissue appearance and distribution in the human fetus *
}

\author{
Claude Michèle Poissonnet ${ }^{a}$, Alphonse R. Burdi ${ }^{b}$ and \\ Stanley M. Garn ${ }^{\mathrm{c}}$ \\ a Centre de Recherches de Biologie du Développement Foetal et Néonatal, Hôpital Port-Royal, Paris, France, \\ ${ }^{b}$ The University of Michigan Medical School and Center for Human Growth and Development, Ann Arbor, \\ and $^{c}$ The University of Michigan School of Public Health and Center for Human Growth and Development, \\ Ann Arbor, MI, U.S.A.
}

Accepted for publication 13 April 1984

\section{Summary}

Timing of first appearance and subsequent distribution of adipose tissue were assessed in 488 normal-for-age human fetuses. The sample represented each of the three trimesters of normal pregnancies. Light microscopy showed that adipose tissue first appears and progressively develops from the 14th to 24th week of gestation (100-216 $\mathrm{mm}$ crown-rump length) in those areas where it characteristically accumulates after birth. No significant sex differences were found in patterns of early fat deposition. It is suggested that the second trimester of gestation is the critical or key period in fat adipogenesis.

human adipose tissue; prenatal adipogenesis; fat distribution patterns

\section{Introduction}

There is a considerable lack of detailed information on the intrauterine development and distribution of human adipose tissue. The development of subcutaneous fat has been reviewed by Dabelow [4] in human fetuses from 170 to $300 \mathrm{~mm}$ crown-rump length (CRL), at a time when adipose tissue is easily recognizable. But

\footnotetext{
* This work has been approved by the ethical committee of the University of Michigan Medical Center. Consent of the parents was legally required for the submission of the fetuses to the Teratology Unit. Address for correspondence: Dr. C.M. Poissonnet, Centre de Recherches de Biologie du Développement Foetal et Néonatal, Hôpital Port-Royal, 123, Bd. de Port-Royal, 75014 Paris, France.
} 
no extensive morphologic survey has, so far, been made on when and where fat tissue is distributed in the human fetus. To our knowledge, the only study dealing with the chronology of fat formation in the human was published by Berg in 1911 [2]. Although well documented, Berg's report is limited by the relatively small number (41) of specimens used in the investigation. At present, it is still not clear whether fat tissue first develops during the second or third trimester, and in what body areas the emergence of fat is first noticeable. Moreover, there is disagreement concerning the origins of brown and white adipose tissues. In particular, it has not yet been demonstrated whether the so-called brown adipose tissue develops in the same pattern of differentiation as that of the white adipose tissue. These questions have led us to conduct this survey based on a population of human fetuses from the Patten Embryology Research Collection of the University of Michigan.

\section{Material and Methods}

A series of 488 human abortuses of both sexes ranging from 1 to $380 \mathrm{~mm}$ crown-rump length (CRL) (1-42 weeks estimated gestational age) were analyzed. Cases with recorded chromosomal defects and macroscopic abnormalities and/or those associated with maternal pathology were eliminated from the study. The techniques of this investigation include those already used in previous studies of fat cell biology [7,13]. Specimens consisted of serial paraffin sections (at 5, 10, or $15 \mu \mathrm{m}$ ) using routine stains to show fat cell morphology, i.e., hematoxylin and eosin or Masson trichrome. Sex, age (weeks following fertilization), and weight (g) were recorded for each specimen. From embryos measuring 1-65 mm CRL, complete body/head sections were obtained. Due to the increase in size of the growing fetus, areas of body and head sections were selected for specimens measuring over $65 \mathrm{~mm}$ CRL. Subcutaneous and deep fat deposits were recognized from the following regions: (a) head (face): buccal and ocular pads, cheek, chin; (b) neck; (c) thorax: anterior and posterior walls, mammary; (d) abdomen: abdominal wall, perirenal; (e) upper limb: shoulder, forearm, arm and hand; (f) lower limb: gluteal, thigh, leg and foot. Complete examination of these regions was made by light microscopy. The presence or absence of adipose tissue in each specimen was rated or 'staged' according to the following histologic classification, as previously described by the authors [12]: (1) Undifferentiated tissue - consisting of loose connective tissue. (2) Angiogenesis - proliferation of primitive vessels associated with mesenchymal condensation. (3) Mesenchymal lobules - mesenchymal cells differentiating into stellate preadipocytes within a vascular matrix or glomerulus. (4) Primitive fat lobules - appearance of fine fat vacuoles in cell cytoplasm of mesenchymal lobules. (5) Definitive fat lobules - fat lobules well separated from each other by dense septae of perilobular mesenchymal tissue. Associations between the above stages of fat tissue differentiation and either CRL or weight in the six different body regions were measured by treatment with the MIDAS computer programs of the University of Michigan. Sex differences were tested using the Student's $t$-test and one-way ANOVA. 


\section{Results}

Table I indicates that morphologic differentiation of adipose tissue at light microscopic level first appears during the second trimester of gestation (100-216 mm CRL) in both males and females. At the beginning of the third trimester, at about 28 weeks, fat tissue is present in the six principal fat deposit areas.

Throughout the body, fat develops according to the same morphogenic sequence of development as already described in our previous report [12]. Fat lobules are the earliest structures to be identified before the appearance of typical adipocytes. Initially, those lobules which show no evidence of lipid storage are called mesenchymal lobules. Mesenchymal lobules then give rise to primitive fat lobules which contain lipid materials. In the last stage, primitive fat lobules develop into definitive fat lobules, which already resemble fat lobules seen in the newborn infant, and, later, in the adult.

In our human fetal series, adipose tissue becomes noticeable at first in the head and neck, somewhat later in the trunk, and finally in the upper and lower limbs.

TABLE I

Chronology of fat appearance in the human fetus (male and female)

\begin{tabular}{|c|c|c|c|c|c|}
\hline \multirow[t]{2}{*}{ Anatomic regions } & \multirow{2}{*}{$\begin{array}{l}\text { Total } \\
\text { No. } \\
\text { of cases } \\
(n)\end{array}$} & \multicolumn{2}{|c|}{ Begins at } & \multicolumn{2}{|c|}{ Complete at } \\
\hline & & $\begin{array}{l}\text { CRL } \\
(\mathrm{mm})\end{array}$ & $\begin{array}{l}\text { Approximate } \\
\text { fetal age } \\
\text { (weeks) }\end{array}$ & $\begin{array}{l}\text { CRL } \\
(\mathrm{mm})\end{array}$ & $\begin{array}{l}\text { Approximate } \\
\text { fetal age } \\
\text { (weeks) }\end{array}$ \\
\hline \multicolumn{6}{|l|}{ Head (face) } \\
\hline Buccal pad & 333 & 100 & 14 & 153 & 17 \\
\hline Cheek & 330 & 103 & 14.5 & 150 & 17 \\
\hline Chin & 329 & 103 & 14.5 & 150 & 17 \\
\hline Ocular pad & 301 & 113 & 15 & 170 & 19.5 \\
\hline Neck & 216 & 103 & 14.5 & 163 & 18 \\
\hline \multicolumn{6}{|l|}{ Thorax } \\
\hline Anterior wall & 226 & 135 & 16 & 170 & 19.5 \\
\hline Posterior wall & 247 & 113 & 15 & 190 & 20.5 \\
\hline Mammary & 209 & 106 & 14.5 & 156 & 17.5 \\
\hline \multicolumn{6}{|l|}{ Abdomen } \\
\hline Abdominal wall & 226 & 106 & 14.5 & 190 & 20.5 \\
\hline Perirenal & 248 & 113 & 15 & 190 & 20.5 \\
\hline \multicolumn{6}{|l|}{ Upper limb } \\
\hline Shoulder & 220 & 113 & 15 & 216 & 23.5 \\
\hline Forearm & 219 & 131 & 16 & 190 & 20.5 \\
\hline Arm & 226 & 131 & 16 & 190 & 20.5 \\
\hline Hand & 382 & 131 & 16 & 172 & 19.5 \\
\hline \multicolumn{6}{|l|}{ Lower limb } \\
\hline Gluteal & 272 & 131 & 16 & 190 & 20.5 \\
\hline Thigh & 221 & 141 & 16.5 & 212 & 22.5 \\
\hline Leg & 216 & 131 & 16 & 212 & 22.5 \\
\hline Foot & 231 & 131 & 16 & 170 & 19.5 \\
\hline
\end{tabular}


Fat differentiation in head and neck

The first indication of fat tissue appearance in the head is in the facial buccal fat pad area, and then in the cheek and chin subcutis. In these regions, definitive fat lobules are easily recognized by the 17th gestational week. They later form a thick continuous layer that covers the midface from the upper part of the cheek to the chin (Fig. 1). At 17 weeks, lobules are seen infiltrating around the optic nerve and globe. The ocular lobules are more elongated than those in the cheek or chin, and are completely differentiated (stage 5) between the 19th and 20th weeks.

In the neck, adipogenesis is initiated at the same time as in the cheek (14.5 weeks). Mesenchymal and primitive fat lobules (Figs. 2 and 3) are identifiable at first throughout the subcutaneous tissue, particularly in the vicinity of the anterior arch and transverse processes of the cervical vertebrae, then between the neck muscles.

Fat differentiation in the thorax

Adipose tissue is first recognizable in the subcutis of the posterior wall of the thorax at 15 weeks, and is densely distributed around the thoracic vertebrae. At this time, fat also appears in the mammary region. Later, around the 16th week, fat tissue spreads into the subcutis of the anterior thoracic wall.

\section{Fat differentiation in the abdomen}

The first sign of abdominal adipogenesis is seen in the abdominal wall between the 14th and 15th week. Perirenal fat develops by the 15th week within the pararenal fascia and along the aorta, and is completely differentiated after the 21 st week (Figs. 4 and 5).

\section{Fat differentiation in the upper limb}

In describing fat formation in the shoulder, the pectoral region between the upper part of the arm and the clavicle was sampled. Fat differentiates, at first, deeply around the shoulder joint, and rapidly spreads between the muscles and the subcutaneous layers of that region (Fig. 6). The distal regions of the upper limb show presence of fat tissue around the 16th week. Fat in the shoulder appears a week earlier.

In the hand, adipogenesis begins in the subcutis of the palm, then progresses proximally to the wrist and distally into the fingers (Fig. 7).

\section{Fat differentiation in the lower limb}

In the gluteal region (hip and buttock) (Fig. 8) as well as in the thigh, leg and foot, adipose tissue first appears by the 16th week. In the foot (Fig. 9), as in the hand, fat tissue is first identifiable in the sole subcutis. It should be pointed out that by the end of the 23rd week a thickened layer of subcutaneous fat covers the extremities of the limbs, as is seen later in the newborn baby.

\section{Sex differences in adipose tissue distribution}

For each of the six fat deposit areas listed in Table I, statistical analyses were made in order to look for differences in adipose tissue distribution that might be 


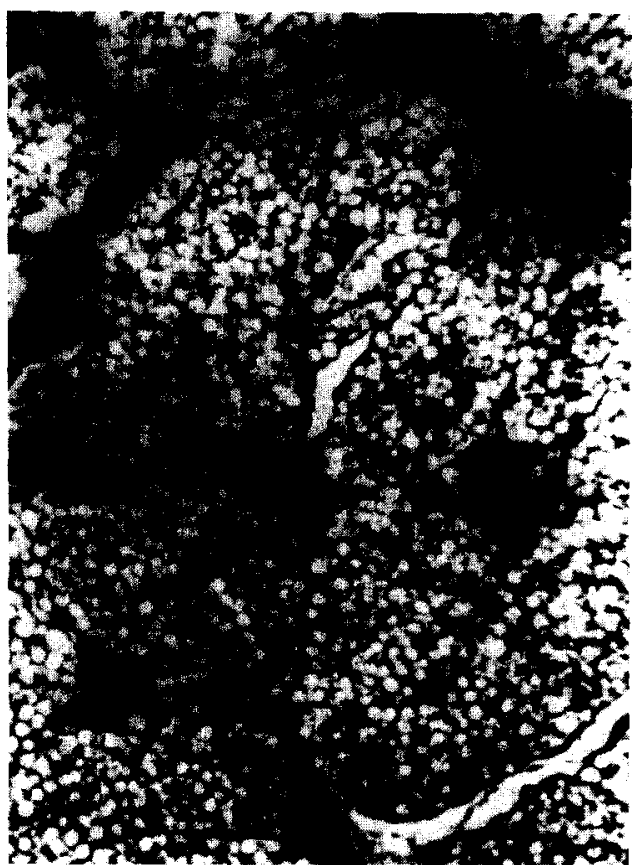

Fig. 1.

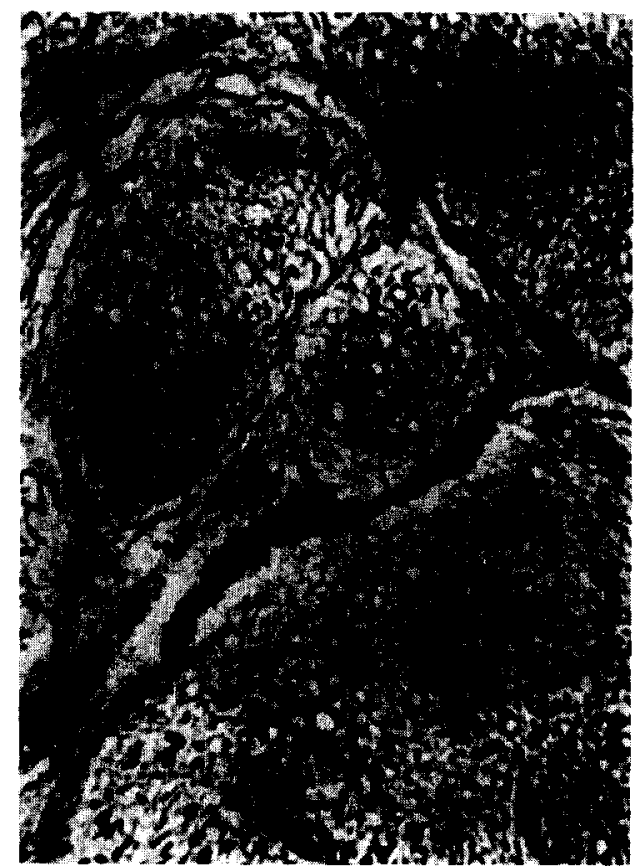

Fig. 3.

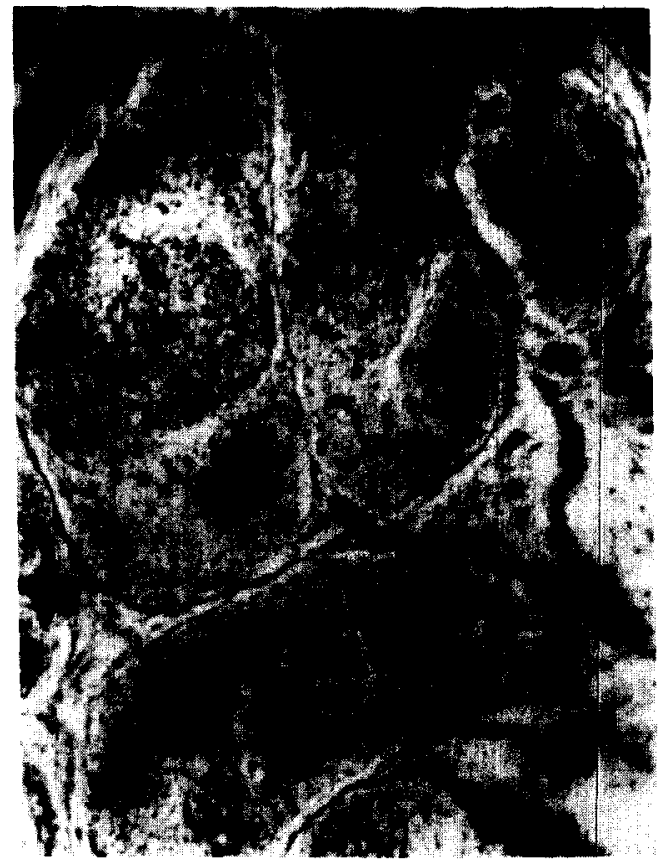

Fig. 2.

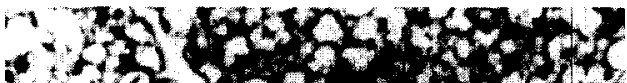

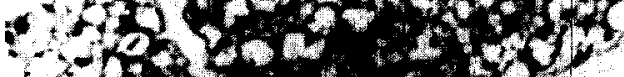

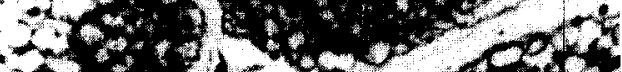

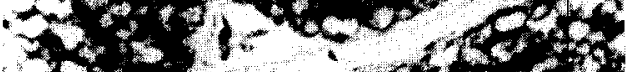

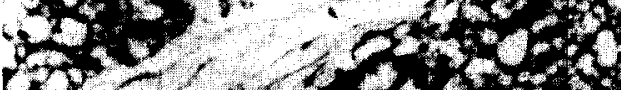

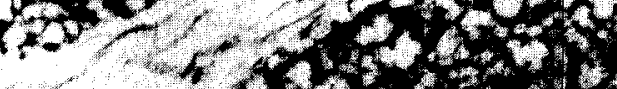

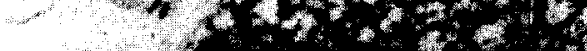

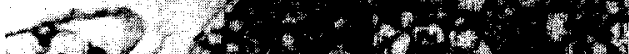

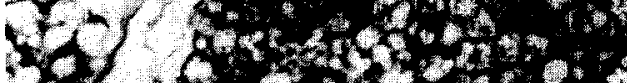

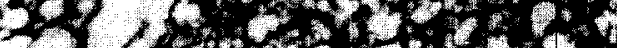

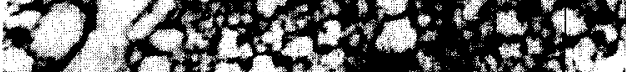

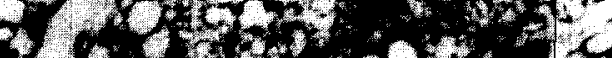
2.

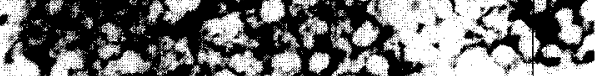

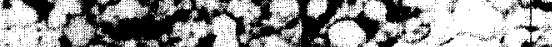

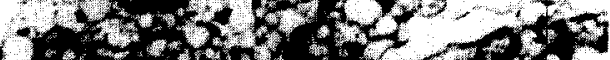

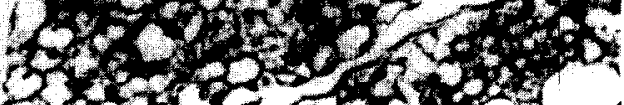

Fig. 4. 
related to sex; no obvious differences were observed in any of the fat deposits from the 14 th week to the end of gestation.

\section{Discussion and Conclusions}

It is generally thought that the last trimester of pregnancy is a critical period for the appearance and development of adipose tissue in the sense that at this time, according to several investigators $[3,6,16]$, the majority of fat tissue is deposited. Our results show that adipose tissue develops as early as the 14-24th weeks of gestation (100-216 mm CRL), i.e., at an earlier time period than previously thought. Available information on the relationship between fetal weight and stages of differentiation shows that bodily adipogenesis does not start until a minimum weight of $125 \mathrm{~g}$ is attained, in both male and female. At a weight of $625 \mathrm{~g}$, adipose tissue is entirely differentiated and laid down in all body sites. These data lead us to identify the second trimester of pregnancy as a critical period in fat development.

This study also indicates that in the human fetus the process of fat formation starts in the head and neck, and rapidly progresses to the trunk, and then to the limbs. It is usually believed that adipose tissue consists of a deep-seated area spread around the various visceral spaces of the trunk, neck, and limbs, and of a subcutaneous area that develops later [10]. This assumption is not exactly true. For example, subcutaneous fat in the face appears before the deep-seated perirenal fat deposit. However, in well vascularized areas such as in the shoulder joint region, fat lobules are identifiable before those in the shoulder subcutis. The importance of angiogenesis in adipose tissue formation has been pointed out by Wassermann [15]. Our results are consistent with Wassermann's studies. It might be emphasized that, in human adipogenesis, fat tissue appears preferentially in areas where capillary proliferation is the more active.

Another finding here is that fat deposition occurs simultaneously in the shoulder, the posterior thorax wall, and in the perirenal area, all of them regions where brown adipose tissue (BAT) is thought to be distributed. The anatomical distribution of BAT was first established by Aherne and Hull [1] in human newborns and older fetuses from 29 to 40 weeks. According to these authors, BAT is mostly found

Fig. 1. Definitive fat lobules (stage 5) in the human cheek region. Note that the lobules are densely packed and form a thick layer of fat ( 24 weeks, $225 \mathrm{~mm} \mathrm{CRL)}$. Masson trichrome stain. $\times 75$.

Fig. 2. Early stage of differentiation of fat lobules in the neck subcutis of a 17-week-old human fetus: mesenchymal lobules (stage 3). Note that at this stage no lipid droplets are visible. Masson trichrome stain. $\times 75$.

Fig. 3. Early stage of differentiation of fat lobules in the neck subcutis of a 17-week-old human fetus: primitive fat lobules (stage 4), showing evidence of lipid storage (arrows). Masson trichrome stain. $\times 175$.

Fig. 4. Definitive fat lobules (stage 5) in the perirenal area of a fetus at term. Note that in Fig. 4, the lobules are more elongated than in Fig. 5. Hematoxylin and eosin stain. $\times 128$. 


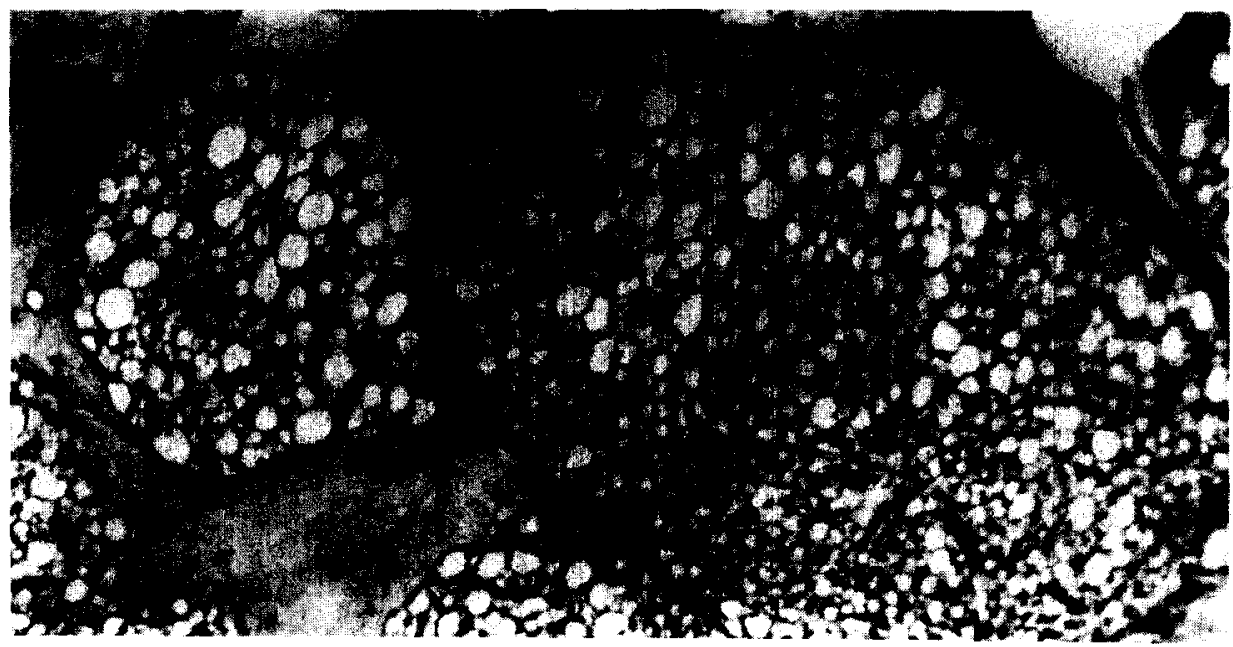

Fig. 5. Definitive fat lobules (stage 5) in the perirenal area in a fetus at term. Hematoxylin and eosin stain. $\times 128$.

between the scapulae, around neck muscles and blood vessels, in the axillae, and around the kidneys and adrenals. However, in Aherne and Hull's report, differentiation of BAT from white adipose tissue is based on rather imprecise cytological criteria, including lipid-free cells and unilocular or multilocular fat cells. Other studies on the distribution of human brown fat $[8,11]$ have used the same criteria of recognition as those of Aherne and Hull. Moreover, these investigations fail to provide information on BAT distribution before 23 weeks. Our study shows that, at

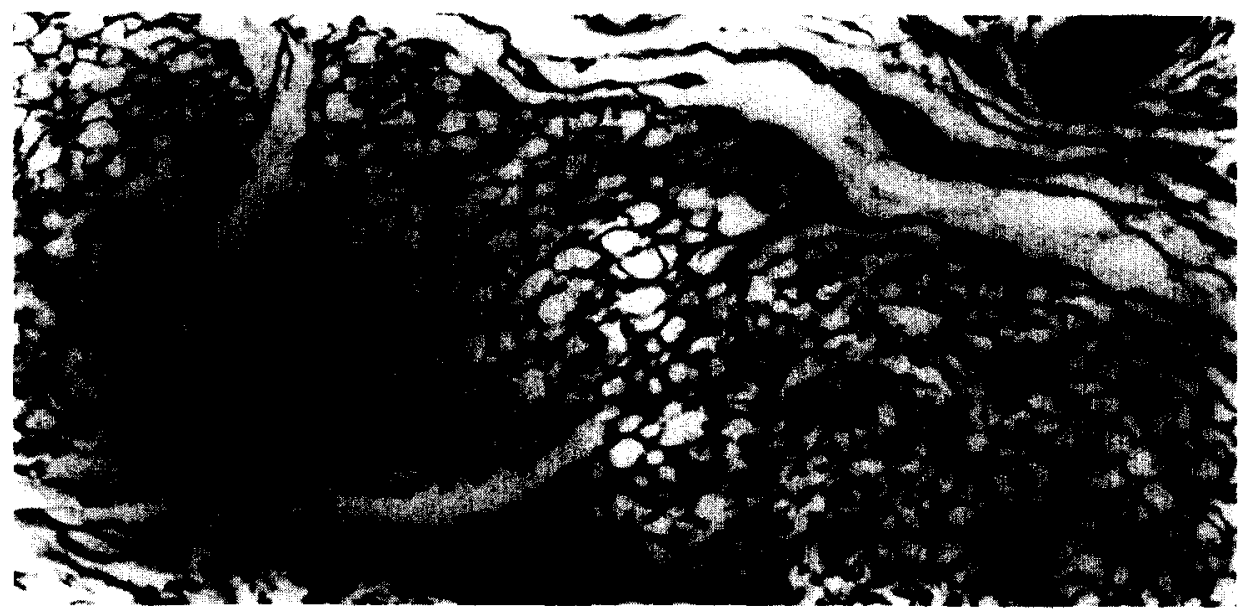

Fig. 6. Definitive fat lobules (stage 5 ) in the shoulder subcutis ( 23.5 weeks, $221 \mathrm{~mm}$ CRL). Hematoxylin and eosin stain. $\times 128$. 


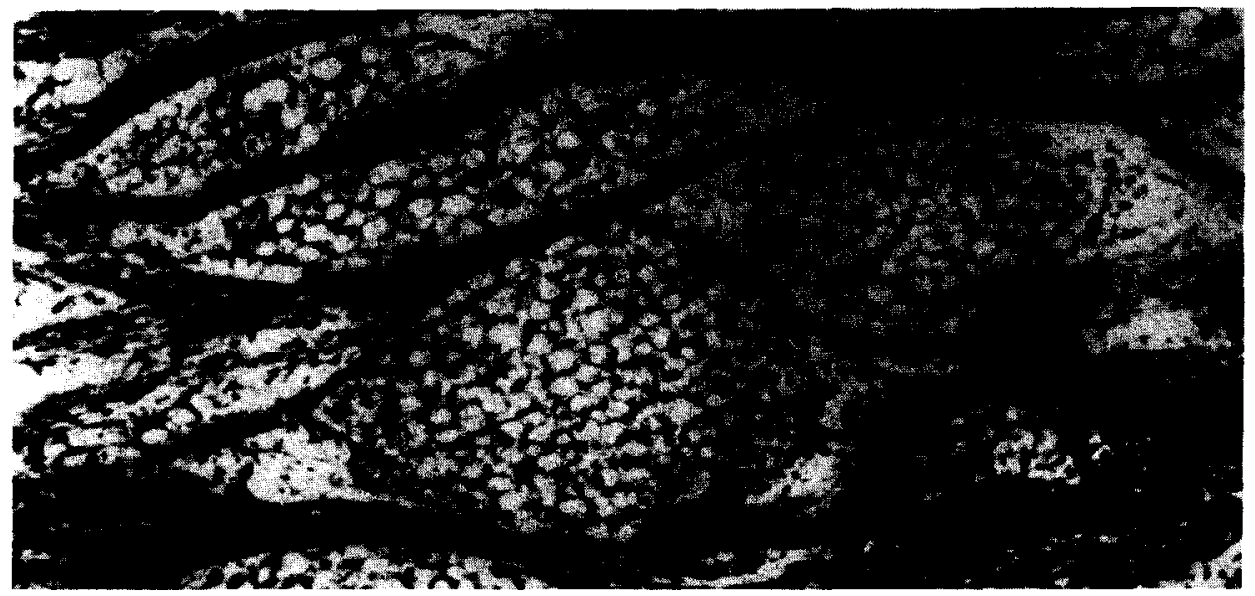

Fig. 7. Definitive fat lobules in hand subcutis ( 26 weeks, $230 \mathrm{~mm} \mathrm{CRL}$ ). Masson trichrome stain. $\times 128$.
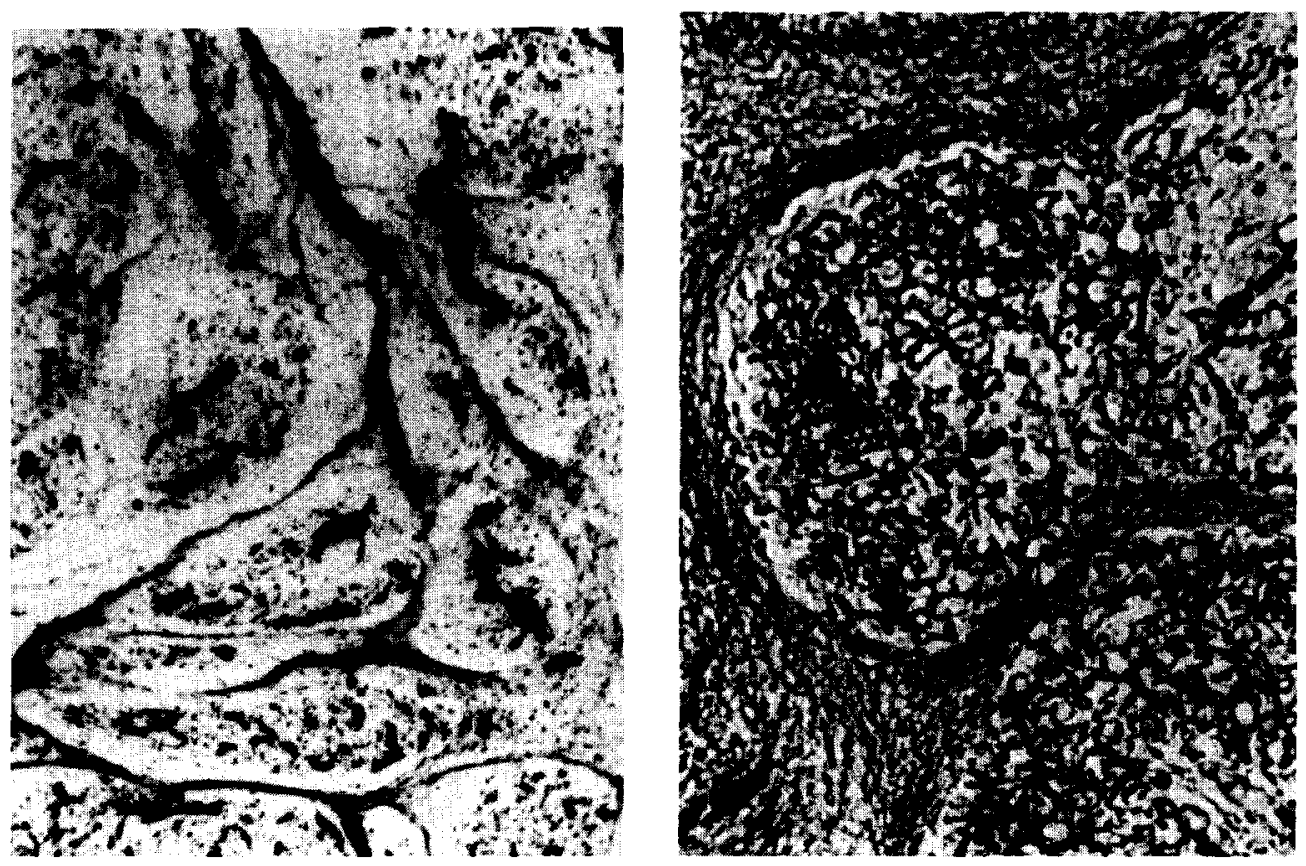

Fig. 8. Mesenchymal lobules (stage 3) in the gluteal region (19 weeks, $163 \mathrm{~mm} \mathrm{CRL).} \mathrm{Masson} \mathrm{trichrome}$ stain. $\times 75$.

Fig. 9. Definitive fat lobules (stage 5) in foot subcutis (28 weeks, $225 \mathrm{~mm} \mathrm{CRL).} \mathrm{Masson} \mathrm{trichrome} \mathrm{stain.}$ $\times 175$. 
the light microscopic level, adipogenesis is comparable in major sites of fat tissue deposition. In these areas, the multilocular aspect of adipose tissue predominates at first, and probably reflects an early stage of development. In the human fetus, lobules are the first structures to be recognizable. They can be considered as developmental markers in adipose tissue formation (Table II). Ultrastructural and biochemical differences between brown and white adipose cells are well established $[9,14]$. However, brown and white adipose tissue cannot be distinguished during prenatal development by light microscopy (Figs. 10 and 11).

With regard to sexual dimorphism in fat deposition patterns, no sex-related differences in adipose tissue distribution were observed, which supports Enzi et al.'s assumption [5] that the marked differentiation between males and females in regional distribution of adipose tissue is not established at birth, but takes place later in childhood. The different factors associated with sex differences in postnatal human adiposity, in particular hormonal factors, seem to have little, if any, influence during gestation.

In conclusion, this investigation identifies the second trimester of gestation as a key period in adipose tissue development. Several clinical implications can be drawn from this study. It has been shown that not only do obese mothers have fatter babies at birth than normal mothers [17], but that their weight gain during pregnancy is associated with increased neonatal fatness and length [18]. This raises the question of whether or not special attention should be given to the diet of the pregnant woman from the 14th week through the end of gestation, in an attempt to reduce the risk of obesity during childhood. Similarly, should diabetes in pregnant women be carefully managed in early gestation in the hope of preventing excessive body fat deposition in the conceptus? Finally, in the evaluation of body size and possible fatness/lean body mass ratios in human fetuses by ultrasonography, it should be kept in mind that the increase in amounts of fat can be seen from the end of the second trimester

\section{TABLE II}

Fat lobules as morphologic developmental markers, first appearance in major anatomic sites in human fetus (in weeks of fertilization and mm CRL)

\begin{tabular}{|c|c|c|c|c|c|c|}
\hline \multirow[t]{3}{*}{ Anatomic } & \multicolumn{2}{|c|}{$\begin{array}{l}\text { Mesenchymal lobules } \\
\text { form (no fat) }\end{array}$} & \multirow{2}{*}{\multicolumn{2}{|c|}{$\begin{array}{l}\text { Primitive fat } \\
\text { lobules appear } \\
\text { (fat storage } \\
\text { begins) }\end{array}$}} & \multicolumn{2}{|c|}{$\begin{array}{l}\text { Definitive fat } \\
\text { lobules defined }\end{array}$} \\
\hline & \multirow[t]{2}{*}{ Weeks } & \multirow[t]{2}{*}{ CRL } & & & \multirow[t]{2}{*}{ Weeks } & \multirow[t]{2}{*}{ CRL } \\
\hline & & & Weeks & CRL & & \\
\hline Buccal pad & 14.5 & 106 & 15.5 & 125 & 17 & 150 \\
\hline Ocular pad & 16 & 131 & 16.5 & 144 & 19.5 & 170 \\
\hline Neck & 14.5 & 106 & 16.5 & 144 & 19.5 & 170 \\
\hline Shoulder & 16.5 & 144 & 19.5 & 172 & 23.5 & 216 \\
\hline Gluteal & 16 & 134 & 16.5 & 144 & 20.5 & 190 \\
\hline Perirenal & 15 & 113 & 19.5 & 170 & 20.5 & 190 \\
\hline Hand & 16 & 131 & 16.5 & 141 & 19.5 & 172 \\
\hline Foot & 16 & 131 & 16.5 & 141 & 19.5 & 170 \\
\hline
\end{tabular}



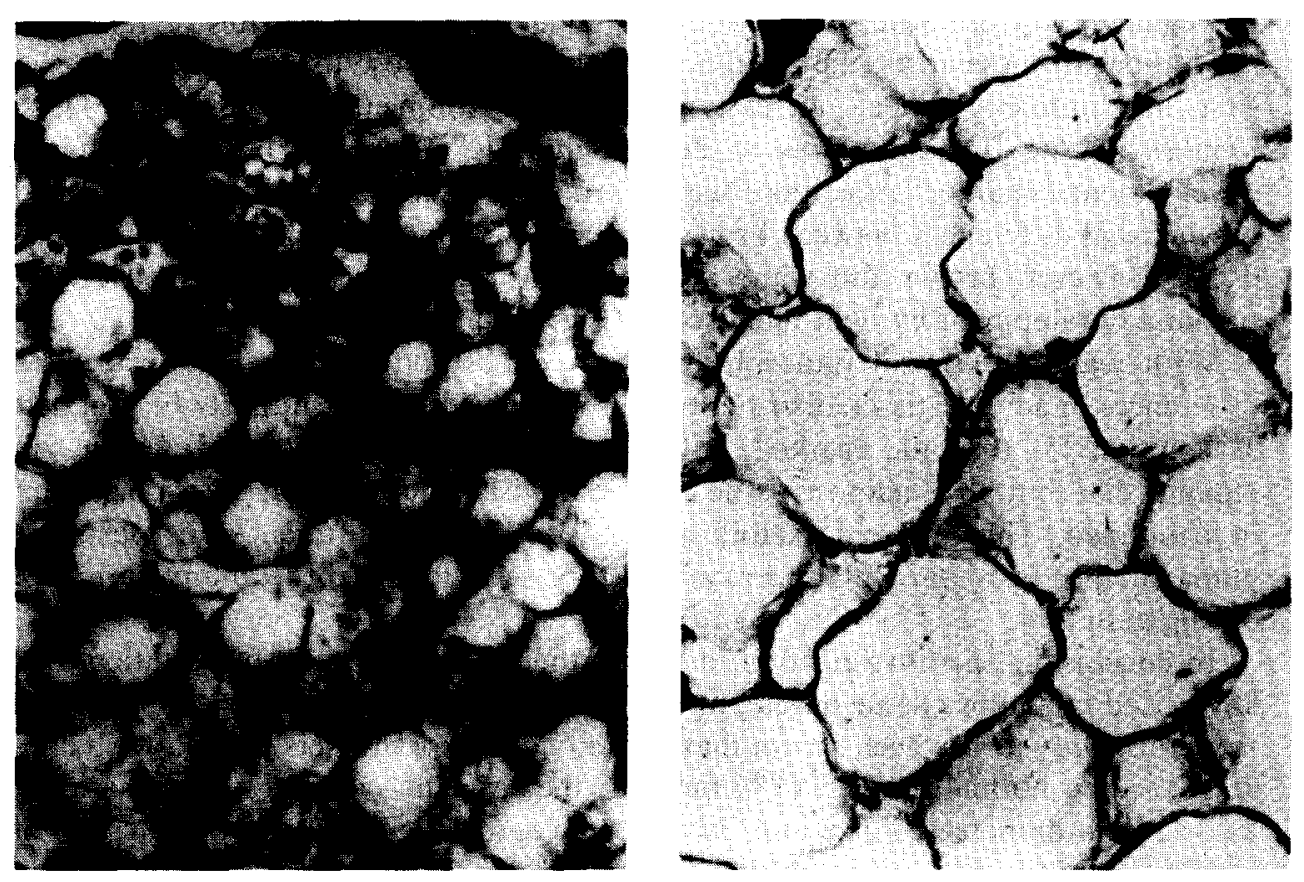

Fig. 10. High magnification of a fat lobule (stage 5) in the buccal pad area. Note that multi and unilocular fat cells are enclosed by a rich capillary network. Masson trichrome stain. $\times 320$.

Fig. 11. Monovacuolar fat cells in the axillary region of a fetus at term. Hematoxylin and eosin stain. $\times 320$.

and not before the 25 th week. Of particular interest would be the ultrasonic determination of thickness of subcutaneous fat in the hand and foot as an indicator of fetal adiposity and maturity.

\section{Acknowledgements}

The authors are grateful to Robert $\mathrm{L}$. Wainright for assistance in data processing and to Dr. Minu Sabet for photography. This research was supported by a grant to A.R.B. from the Kroc Foundation (U.S.A.).

\section{References}

1 Aherne, W. and Hull, D. (1966): Brown adipose tissue and heat production in the newborn infant. J. Pathol. Bacteriol. 91, 223-234.

2 Berg, W. (1911): Uber die Anlage und Entwicklung des Fettgewebes beim Menschen. Z. Morphol. Anthropol. 13, 305-341.

3 Brook, C.G.D. (1978): Cellular growth: adipose tissue. In: Human Growth 2, pp. 21-33. Editors: F. Falkner and J.M. Tanner. Plenum Press, New York and London. 
4 Dabelow. A. (1957): Die Entwicklung der Fettorgane im subcutanen Gewebe menschlicher Feten. Verh. Anat. Ges. (Jena) 54, 83-96.

5 Enzi, G., Inelmen, E.M., Caretta, F., Rubaltelli, F., Grella, P. and Baritussio, A. (1980): Adipose tissue development 'in utero'. Relationships between nutritional and hormonal factors and body fat mass enlargement in newborns. Diabetologia 18, 135-140.

6 Enzi, G., Zanardo, V., Caretta, F., Inelmen, E.M. and Rubaltelli, F. (1981): Intrauterine growth and adipose tissue development. Am. J. Clin. Nutr. 34, 1785-1790.

7 Gurr, M.I. and Kirtland, J. (1978): Adipose tissue cellularity: a review. 1. Techniques for studying cellularity. Int. J. Obes. 2, 401-427

8 Heaton, J.M. (1972): The distribution of brown adipose tissue in the human. J. Anat. 112, 35-39.

9 Hull, D. and Segall, M.M. (1966): Distinction of brown from white adipose tissue. Nature 212, 469-472.

10 Knittle, J.L. (1978): Adipose tissue development in Man. In: Human Growth, Vol. 2, pp. 295-315. Editors: F. Falkner and J.M. Tanner. Plenum Press, New York and London.

11 Merklin, R.J. (1974): Growth and distribution of human fetal brown fat. Anat. Rec. 178, 637-646.

12 Poisonnet, C.M., Burdi, A.R. and Bookstein, F.L. (1983): Growth and development of human adipose tissue during early gestation. Early Hum. Dev. 8, 1-11.

13 Slavin, B.G. (1973): Fat. In: The Encyclopedia of Microscopy and Microtechnique, pp. 146-148. Editor: P. Gray. Van Nostrand Reinhold, New York.

14 Smalley, R.L. (1970): Changes in composition and metabolism during adipose tissue development. In: Brown Adipose Tissue, pp. 73-95.

15 Wassermann, F. (1965): The development of adipose tissue. In: Handbook of Physiology. Sect. 5: Adipose Tissue, pp. 87-100. Editors: A.E. Renold and G.F. Cahill. American Physiological Society, Washington D.C.

16 Watson, F.H. and Lowrey, G.H. (1967): Growth and Development of Children, p. 69, Year Book Medical Publishers Inc., Chicago.

17 Whitelaw, A.G.L. (1976): Influence of maternal obesity on subcutaneous fat in the newborn. Br. Med. J. 1, 985-986.

18 Udall, J.N., Harrison, G.G., Vaucher, Y., Walson, P.D. and Morrow, III, G. (1978): Interaction of maternal and neonatal obesity. Pediatrics 62, 17-21. 